Article

\title{
An Exploration of the Value of Timeless Design Styles for the Consumer Acceptance of Refurbished Products
}

\author{
Theresa S. Wallner *, Lise Magnier and Ruth Mugge
}

Delft University of Technology, Faculty of Industrial Design Engineering, 2628 CE Delft, The Netherlands; l.b.m.magnier@tudelft.nl (L.M.); r.mugge@tudelft.nl (R.M.)

* Correspondence: t.s.wallner@tudelft.nl; Tel.: +31-682-787-757

Received: 20 December 2019; Accepted: 4 February 2020; Published: 7 February 2020

\begin{abstract}
The prior use and age make refurbished products a less desirable option because they are perceived to be of lower quality, to have a reduced performance and a less attractive appearance. This research investigates one strategy on how to enhance the appearance of refurbished products and thereby encourage circular consumption via refurbishment. In 21 in-depth interviews, we explore whether embodying refurbished products in a timeless design can serve as a potential strategy to influence consumer acceptance of refurbished products. Specifically, we examined two design styles that were proposed as timeless: the neo-retro design style, which evokes nostalgia and benefits from associations with the past, and the simplistic design style, that is independent of cultural or time-related cues. Our findings provided qualitative support that the neo-retro and the simplistic design styles can improve consumers' evaluations of refurbished products. Both design styles were considered to be timeless and elicited favorable associations in consumers. While refurbished products, following a neo-retro design style, evoked positive associations with old products, such as feelings of nostalgia and the good quality of the past, simplistic products benefited from associations with durability and associations with high-quality brands.
\end{abstract}

Keywords: refurbished products; timeless designs; consumer acceptance; neo-retro design style; simplistic design style; circular economy; product appearance

\section{Introduction}

In the European Union, more than 8 million $\mathrm{kg}$ of electronic waste is annually produced [1]. Most of the electronic waste that is currently produced ends up in landfills, where it can harm the environment by releasing toxins into the atmosphere and the groundwater. At the same time, resources that are used to build electronic devices become more and more sparse. A smartphone, for example, contains 42 different minerals on average; all of which are not only finite but also mined at the expense of the environment and great human costs [2].

\subsection{Circular Economy}

A promising path to sustainable development is the circular economy. The circular economy aims to replace our current take-make-waste model of producing products (linear economy) with a "regenerative system in which resource input and waste, emission, and energy leakage are minimized by slowing, closing, and narrowing material and energy loops. This can be achieved through long-lasting design, maintenance, repair, reuse, remanufacturing, refurbishing, and recycling" [3] (p. 766). In the circular economy, the production of waste and use of virgin resources is minimized, which can contribute to more sustainable production and consumption. In the current linear economy, most value of products is lost when these are discarded after their use phase. In the circular economy, value is however retained because it is restorative by design: materials for the production of consumer 
goods, components of products, and finally, complete products are recovered and restored through various circular strategies. The most preferred strategies in a circular economy try to maintain the highest utility and value and thus, keep consumer products intact by aiming for extended use periods either with the first owner or a successful second life via refurbishment or remanufacturing. These circular strategies save production costs, such as energy, water, and virgin resources needed to manufacture new products.

\subsection{Refurbishment is a Solution to Our Waste and Resource Problem}

Within the circular economy, refurbishment is therefore seen as a key circular strategy to extend the lifetime of consumer products and keep them in the loop as long as possible. Refurbished products are second-hand products that were recollected after their first use, subsequently tested and restored into an acceptable state before they are resold to consumers [4].

From an environmental perspective, in refurbishment only dysfunctional parts are renewed; it can, therefore, save up to $70 \%$ virgin materials, $90 \%$ water, and $80 \%$ pollutant emissions compared to manufacturing new products, and therefore has a lower environmental impact than new products or remanufactured products [5]. Refurbishment is a good strategy, especially for products that cannot be repaired by consumers themselves or are discarded before the end of their functional life [6].

From a market perspective, refurbishment seems a promising circular strategy to save material resources. It keeps products in the loop for a longer period of time and can create a competitive advantage for companies when, in the future, finite resources will inevitably become scarce and hence, will increase in prices [7]. Refurbishment is, however, only profitable for companies if consumers buy refurbished products. For consumers, refurbished products are an economical choice because their market value is $10-50 \%$ lower than the market value of new products. Although environmental and financial benefits, as well as warranties, offer rational reasons to buy refurbished products, these benefits are not sufficient for most consumers to consider refurbished products as a viable alternative to new ones [8].

\subsection{Low Consumer Evaluations of Refurbished Products}

While it is commonly accepted to buy refurbished cars and bicycles, other refurbished consumer goods, such as coffee makers, headphones or water kettles are not a popular consumer choice yet [9], and remain a challenge in the transition to a circular economy [10]. Consumers are generally willing to pay less money for refurbished products and show lower purchase intentions [8,11-17]. Furthermore, consumers think that refurbished products are a riskier choice or find touching a refurbished product uncomfortable because of physical or digital traces a former user might have left on the product [18]. Another disadvantage of refurbished products is their aesthetic appearance; refurbished products are often considered to have a less attractive appearance than new products for two reasons: First, refurbished products can lack a desired new look and do not follow the latest trends. Second, wear and tear signs can make the product less desirable because these signs remind the user of the product's previous use, thereby triggering negative associations that the product may not function as well as a'new product [19].

While most research on consumer acceptance of refurbished products has focused on functional characteristics $[7,20,21]$, research on aspects related to product appearance is scarce [22,23]. This research explores a potential strategy to enhance the appearance of refurbished products by giving these products a timeless design. Timeless designs are generally perceived to be attractive for a longer time and are not as sensitive to trends $[24,25]$. We contribute to the current literature by exploring how refurbished products should look like to remain desirable during multiple lifecycles. Specifically, we focus on the value of timeless designs for positively influencing consumer acceptance of refurbished products. Precisely, we use qualitative research to acquire in-depth knowledge of how individuals derive meaning from the appearance of refurbished products following different timeless design styles, and how the product's meaning influences consumers' attitudes. 


\subsection{Enhancing Consumer Acceptance of Refurbished Products Via Product Appearance}

In the literature, it has been established that the appearance of the product gives the user information about the utility of a new product [26-28] and consumers use product appearance as a cue for quality [23,29-31].

One of the few articles on the appearance of refurbished products has revealed that their appearance influences consumer acceptance of refurbished products [22]. Specifically, it was found that if wear and tear signs were present on a smartphone, participants were less likely to buy the refurbished smartphone and wanted to pay less money for it than for a smartphone without scratches. Participants worried that the product was contaminated with physical or digital traces of previous owners. Additionally, participants were afraid that the product would become obsolete because it might not be possible to update the software of the product. In Mugge et al.'s research [22], a standard Apple iPhone 5 was investigated, and thus, the effect of appearance was investigated by looking only at the impact of wear and tear. It would, however, be compelling to complement this research by investigating other appearance characteristics, such as the specific design style and to which extent this design style is judged to be timeless.

\subsection{Timeless Designs}

Specific design styles, such as timeless designs, are less affected by time and "ever-changing consumer tastes" than other design styles [24] (p. 2), and therefore remain to be evaluated positively throughout time [26]. According to Lobos [24], timelessness consists of aspects related to the functionality and appearance of the product. While functionality can be made timeless by designing a product that is repairable and upgradable, achieving timelessness in the appearance is related to creating a product that is either unique or by disconnecting it from popular aesthetic cues that will serve as an indicator of time [24,32]. Lobos' ideas on timelessness were further developed by Flood Heaton and McDonagh [33] who suggested the following three possible strategies to create a timeless product appearance: Exceptionally beautiful designs, nostalgia evoking designs and simplistic designs.

\subsubsection{Strategy 1: Exceptionally Beautiful Designs}

Creating beautiful forms was described as the first strategy to achieve timelessness in product appearances. Flood Heaton and McDonagh [33] describe that exceptionally beautiful designs trigger a "dramatic emotional response" of pleasure (p. 112) in the consumer, which seems to increase the timelessness of the design, perhaps because the product appears to be particularly unique [24] or because it communicates being of high quality to the consumer as a result of the "What is beautiful is good principle" [34] (p. 285). Even though some general design principles for creating attractive products are known [35-38], the experience of the beauty of a product is also highly subjective and varies between different consumer groups [39]. Consequently, Flood Heaton and McDonagh [33] see more potential in the other two strategies to create timeless designs.

\subsubsection{Strategy 2: Nostalgia Evoking Designs}

Nostalgia evoking designs are considered timeless because of their associations with the past and were suggested to prolong the emotional durability of a product [40] by integrating values, such as fine craft, innovation and the historical context into the design. Even though nostalgia evoking products may not have been exceptionally popular at the time of their first creation, their cultural and historical context makes them aesthetically appealing now. One possibility to evoke nostalgia with products is by implementing design characteristics from the past into new designs, such as in the neo-retro design style.

Neo-retro products are technologically up-to-date and show significant design characteristics from the past while still conveying information that these products offer new functionalities [41]. One 
example is the Medion life retro radio (see Figure 1). It has an old wooden frame that antique radios often had in the past, but the display indicates that the radio has new functionalities.
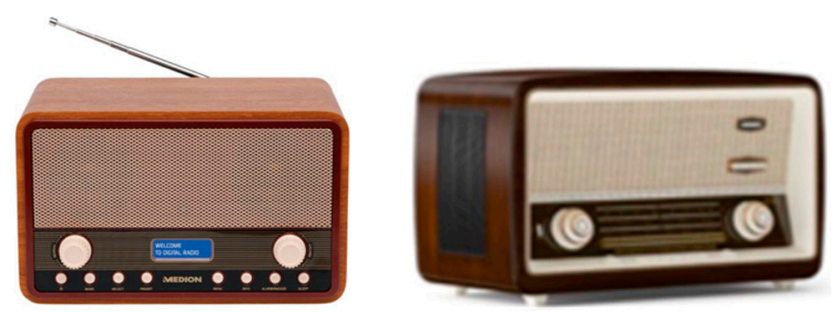

Figure 1. The Medion life retro radio (left) shows neo-retro design style features. While it has a wooden frame that is comparable to an antique radio (right), the LCD display shows that the product offers new functionalities.

Although it is suggested that integrating nostalgia evoking elements into the design of a new product makes the product timeless and can be used as a strategy to increase the longevity of the product, it remains unclear whether this strategy can benefit refurbished products as well. In principle, refurbished products show similarities with both old and new products. On the one hand, refurbished products have previously been used by others and are thus old products. On the other hand, refurbished products are thoroughly checked and if needed, repaired to offer similar functionality as a new product. Taking into account this duality, it is interesting to explore if embodying refurbished products in the neo-retro design style can help to transform the prior use and age of the product into a desirable state. By evoking positive historic and contextual associations with old products, refurbished products following a neo-retro design style could improve consumer evaluations of refurbished products.

\subsubsection{Strategy 3: Simplistic Designs}

The third strategy to achieve timelessness in the design of refurbished products consists of creating simplistic products. Simplistic designs generally seek simplicity without losing correspondence "to the essential nature of the product" [33] (p. 112). They are characterized by an internal arrangement that is symmetrical, ordered, and harmonious. Simplistic designs are balanced in proportion, have little contrast in color, make use of pure and cold materials [39] and are still highly prototypical.

Prior research has suggested that products that follow the simplistic design style (also referred to as classic designs) may remain strongly preferred over time as they do not follow fast trend cycles $[24,42]$. Designs with as little ornaments as possible were suggested to be independent of cultural and time-related cues, and consequently timeless [24]. Visually simplistic product appearances can, hence, extend the lifetime of products [33]. An example is Dieter Rams' Braun T3 pocket radio that was designed in 1958. Dieter Rams' design principles include that design should be long-lasting, environmentally friendly and as little design as possible [43]. Following his principles, the radio is simplistic in its design, is symmetric, and uses little color but still looks like a prototypical radio (see Figure 2). While Dieter Rams designed this radio already in the late 50s, his designs are still deemed beautiful and have inspired many modern designs, such as the design of the Apple iPod [44]. Making the first version of a product that is as timeless could benefit the consumer acceptability of the product when it is refurbished in later life cycles.

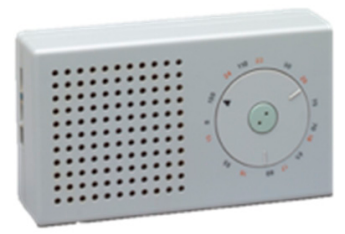

Figure 2. The T3 Braun Pocket Radio designed by Dieter Rams in 1958. 
In this study, we focus on nostalgia evoking and simplistic designs because they have not yet been researched in the context of refurbished products and are, therefore, subject to our study.

\section{Materials and Methods}

The principal investigator visited participants $(N=21)$ at home to conduct semi-structured, in-depth interviews. All participants were selected from a university-based research panel $(M=50$, 2 years old, ten females). We selected 21 participants of various backgrounds in terms of age (age range 28-76) and socio-economic backgrounds because of the exploratory nature of this study. Specifically, we wanted to capture how different consumers perceive refurbished products and were interested in the full spectrum of responses, rather than focusing on one specific target group. Prior research concluded that different target groups may choose refurbished products for different reasons [8] and thus it is important to include a diverse group of participants to provide a comprehensive understanding of the influence of specific design styles on responses to refurbished products. In addition, the circular economy will only have significant effects if many consumers are willing to turn to circular alternatives, such as refurbished products.

We decided to interview a total of 21 participants to ensure data saturation. Data saturation is achieved when any new interview only delivers approximately one or two additional codes. To achieve data saturation for heterogeneous groups, $12-16$ participants $[45,46]$ are proposed to be interviewed.

The interviews took place at participants' homes, which enabled participants to show and discuss their refurbished and second-hand products.

During the in-depth interviews, participants were asked to respond to 18 stimuli pictures (see Figure 3, for example, stimuli) belonging to three product categories (coffee makers, headphones, and radios) that varied in their design style (neo-retro, simplistic and prototypical). The stimuli were used to evoke associations with refurbished products. We chose coffee makers, headphones, and radios because they are not highly technologically advanced, offer opportunities for refurbishment and are offered in multiple design styles, such as the simplistic and neo-retro design styles.
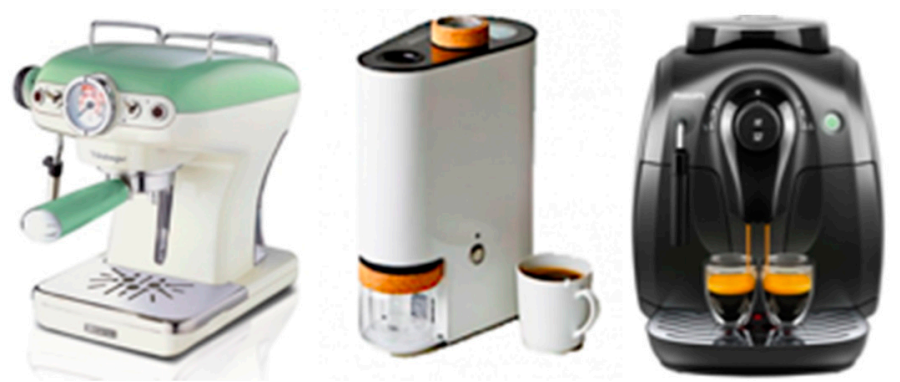

Figure 3. Example stimuli displaying coffee makers in the neo-retro design style (Ariete, left), simplistic design style (Ikawa, middle) and prototypical design (Philips, right).

We included prototypical designs to the stimuli to uncover differences in evaluations between refurbished products with a timeless appearance (following either a neo-retro or simplistic design style) and refurbished products with more 'ordinary' appearances (following a prototypical design style) that are not suggested to be timeless.

\subsection{Pre-test}

All stimuli were selected based on a pre-test to evaluate their design style. In this pre-test, 54 designers and design students (2-34 years of design experience, $\mathrm{M}=7.34$ years of design experience, $52 \%$ female) rated 45 images of the product categories of coffee makers, headphones and radios on the degree to which the stimulus product showed design characteristics that are neo-retro, simplistic, or prototypical of the product category on a 7-point scale $(1=$ Completely Disagree; $7=$ Completely Agree; for means see Table A1). We used designers and design students to obtain an expert opinion 
on the design styles. For the neo-retro design style, six stimuli (two for each product category) were selected with high scores on both neo-retro, medium scores on prototypical, and a low score on simplistic. For the simplistic design style, we selected six stimuli with high scores on simplistic and medium to high scores on prototypicality and a low score on neo-retro. Finally, for the prototypical design style, we selected six stimuli with a high score on prototypical, and low scores for neo-retro and simplistic (see Table A1).

\subsection{Main Study}

During the interviews of the main study, the participants were first asked to elaborate on their initial perceptions towards refurbished and other second-hand products, such as antiques (for example: "Have you ever bought a refurbished product?"; If yes: "Why did you decide to buy a refurbished product?"). Second, they were shown the 18 stimuli pictures. We explained that the products on the pictures were refurbished, after which participants were asked questions about their perceptions of these products (For example, "Which of these refurbished products do you like best?"; "What are your associations with the product given that it is refurbished?"). We specifically asked participants to compare the different stimuli to uncover the effects of different design styles in refurbished products (for example: "What do you think about the quality of this product compared to the other products?"; "Which product do you think you could use for the longest time? Explain why"). Participants received a small compensation (10 euros voucher) for their participation.

\subsection{Data Processing}

All interviews were audio-recorded and transcribed by the principal investigator. Subsequently, the transcriptions were coded using Atlas Ti and analyzed. Codes emerged during two coding rounds, which were inductive. The first five interviews were analyzed in a collaborative session of all authors, which resulted in 144 codes. The remaining 16 interviews were analyzed by the principal investigator and resulted in a total number of 259 codes in the second coding round. Data saturation was reached after the 18th interview, suggesting that our sample size was sufficient. The first-order codes were discussed in the research team, adapted and summarized into 88 second-order codes that were sorted into 29 themes (see Table 1 for an example theme). These first- and second-order codes and themes were discussed and agreed upon by the full research team. For this paper, 19 out of 32 themes (see Table A2) were used.

Table 1. Coding structure.

\begin{tabular}{lll}
\hline Theme & Second-order Code & First-order Code \\
\hline $\begin{array}{l}\text { Neo-retro products evoke } \\
\text { associations with the past. }\end{array}$ & $\begin{array}{l}\text { Neo-retro refurbished products } \\
\text { evoke sentimental feelings, which } \\
\text { can make them more desirable. }\end{array}$ & $\begin{array}{l}\text { Neo-retro refurbished products evoke } \\
\text { feelings of nostalgia. }\end{array}$ \\
& Nostalgia determines product choice. \\
\hline
\end{tabular}

\section{Results}

In the next section, we elaborate on our findings related to the general motivations to buy refurbished products, the evaluations of refurbished products following either the neo-retro or simplistic design styles, and the general design characteristics that were identified to make refurbishment more attractive to consumers.

\subsection{Motivations to Buy Refurbished Products}

In general, participants named two main motivations to buy refurbished products: the lower economic costs and environmental benefits, confirming prior research $[15,19,47]$. Participants either had bought refurbished products in the past because they were cheaper than new products and 
refurbishment offered them the possibility to go for a premium product, such as an Apple iPad instead of a cheaper tablet brand. Other participants mentioned that they had purchased refurbished products because reusing products saves natural resources and reduces the amount of waste that is produced. Even though participants proposed these motivations to buy refurbished products, one participant suggested that the design should seduce the consumer more to buy refurbished products.

Participant 3: "We can, of course, all shout out that nobody should produce new goods anymore because we already have enough products on our planet, but I think we should all be looking to reuse things. But it would be great if the design would seduce us to do so."

\subsection{Role of Timelessness in the Design of Refurbished Products}

Concerning the effects of different design styles, our findings provide preliminary qualitative support for the value of both the neo-retro design style and the simplistic design style for improving consumers' evaluations of refurbished products in comparison to refurbished products with a prototypical design style. The prototypical designs did not trigger inferences on timelessness; prototypical designs were therefore only discussed as a frame of reference for the results of the other design styles.

\subsubsection{Evaluations of Refurbished Products in a Neo-retro Design}

Participants evaluated refurbished products in a neo-retro design to have a timeless design because the neo-retro design style was perceived as less vulnerable to trends than prototypical designs. Participants argued that if it was beautiful in the past and is still beautiful now, it would be aesthetically appealing in the future as well, which makes the design timeless.

Participant 4: "I think I would choose (headphone) number 8 (to be beautiful for the longest time) because it just seems more timeless."

This is in line with research proposing that timeless designs evoke nostalgic feelings in the consumer by integrating values, such as fine craft, innovation, and historical context into the design [26].

Refurbished products in a neo-retro design were described to look like 'old' products and therefore, evoke associations with such products in terms of looks and usability. Several participants mentioned that neo-retro products reminded them of antiques, Art Deco, vintage or other old products. This association was generally positive because products in the past were "made to last,", and would thus have a reduced chance to break down prematurely. As a consequence of this long-lasting value, a neo-retro design style was considered more desirable for products that are bought in a second or even later life cycle after refurbishment.

Participant 12: "I think it is an unconscious choice, but I would choose (coffee machine) 1 or 2 because they have an antique appearance and with that comes some sort of eternal value."

Participants also expected refurbished products in a neo-retro design style to have 'old' functional features, such as mechanistic buttons or wheels that are not necessarily used in today's products. This made the product fun to use for some participants who considered these 'old' features to be positive. Others just mentioned that they expected such 'old' functional features, but this did not determine their product choice. For example, in the neo-retro radios 13 and 14, participants expected the wheels to make squeaking sounds or to be rickety even though they knew that the product was modern in a refurbished state.

Participant 6: "Yes, 13. We had such a radio in the past. My association with it is that the wheel is squeaking. It appears to be old. It could be really modern from the inside, but you cannot see this from the outside." 
Refurbished products in a neo-retro design style also reminded people of the "good old times." Participants appreciated this because it reminded them of the good old times, or they simply liked the look of products from that time because of their historic associations. Participants also associated these refurbished products with a feeling of nostalgia. Multiple participants said that the neo-retro coffee machines 1 and 2 evoked nostalgic feelings about the American sixties (coffee machine 1) or an Italian espresso bar (coffee machine 2) and triggered warm memories of experiences in Italy or the United States.

Participant 10: "I would choose this one (coffee machine 2) because I've always liked this one. It's not a real argument, more a form of nostalgia. It reminds me of my vacation in Italy before they used these espresso machines here in the Netherlands."

While some participants said that the feelings of nostalgia also determined participants' product choice for the refurbished products in a neo-retro design style, others said that nostalgia was good but that the quality of the object was still more important. An important drawback of current refurbished products is that people perceive them to have lower quality than new products [15,48]. Interestingly, when presented with pictures of refurbished products in a neo-retro design style, participants did not express such negative associations. Participants even indicated that refurbished products in a neo-retro design style looked durable, solid, and robust and reminded them of the good quality of the past. Participants proposed that products of the past were made to last while they believed that today's products often break down prematurely, also known as planned obsolescence.

Participant 8: "I think that the quality is more or less the same for all products but that (coffee maker) 1 and 2 are better than number 5 because they (1 and 2) are classic models like they were built in the past. In the past, everything was built so that it would last for as long as possible. At the moment, [it is designed] for just three years because otherwise, they don't earn enough money anymore. So, I think that 1 and 2 could be more durable."

Another disadvantage of the refurbished products that are on the market nowadays is that consumers do not receive information about their prior use or history of the product [19]. Other kinds of second-hand products, such as antiques, often benefit from the fact that people believe that there is a narrative attached to the product, which provides extra emotional value and makes the product special. Refurbished products are usually not associated with having a narrative. However, our findings provide some first insights that the appearance of the refurbished product can play a role in triggering such a narrative. Specifically, some participants mentioned that refurbished products following a neo-retro style evoke associations with the products, having a narrative more than simplistic or prototypical products.

Participant 14: "I think that some refurbished products have a story. Not all, of course. [ ... ] It depends on your own interpretation. (Coffee machine) 1, really has a story, and the other ones don't have that at all. I think it is an unconscious choice. A so-called unconscious choice that is probably related to my memories. The weird thing is that I have no memories of it because I had not been born in that time yet."

Participants suggested that refurbished products in a neo-retro design style looked unique, charming, prominent, extravagant, and more beautiful than other refurbished products, because of their old appearance. One participant also said that the 'old' look of a refurbished product in a neo-retro design style gives it an extra value because the appearance is more attractive. Participants appreciate the use of wood in radio 14 and thought that the metal parts of headphone 8 and coffee maker 1 and 2 made the products more robust.

Participant 2: "It looks like an old-fashioned radio (radio 13). And that wooden cover, not plastic. I think that is just more beautiful. That is the reason why I would choose that one." 


\subsubsection{Evaluations of Refurbished Products in a Simplistic Design}

Our findings suggested that refurbished products following a simplistic design style were considered to have a timeless design as well. Nevertheless, the underlying reasoning for the value of a simplistic design style for creating a timeless experience and thereby improving consumers' evaluation of refurbished products differed from that of refurbished products in a neo-retro design style. Specifically, participants explained that they perceived the refurbished products in a simplistic design style as timeless because these were not associated with any particular time in history.

Participant 6: "Yes, I think that I would use (radio 15) it the longest because it is so independent of... it is just really timeless."

Refurbished products in a simplistic design style were not related to any period of time and therefore considered timeless. This is in line with the suggestion that some products are timeless because the design is independent of time-related cues [24].

One reason why consumers often prefer new products over refurbished products is the appearance of refurbished products [22]. Refurbished products often do not have an as-new appearance and sometimes do not follow the latest trend and may, therefore, be less desirable. Refurbished products in a simplistic design style were, however, described as inconspicuous, simple-looking, nice and easy to use, and were preferred over prototypical products because of their inconspicuous appearance.

Participant 11: "I think I would choose (radio) number 15 because it looks good in different kinds of interiors because it is really inconspicuous. That's good!"

Refurbished products are generally associated with lower quality than new products $[15,48]$. Our findings suggest that specific appearances may diminish this negative quality effect. Specifically, refurbished products in a simplistic design style were perceived to have a higher quality compared to prototypical products. The provided rationale for this difference in quality was that refurbished products in a simplistic design style reminded participants of objects that were designed by high-quality brands, such as Apple or the Dieter Rams' Braun designs. As a consequence, participants favored this design style in refurbished products over more prototypical designs.

\section{Participant 12: "I would go for (radio) number 15. It has this Apple look. I think it is really beautiful."}

From the appearance of refurbished products in a simplistic design style, participants also inferred that the product is so simple that nothing can break, such as buttons or the electronics inside of the product. This was considered to be positive because participants preferred durable products.

Participant 18: "Maybe I could use (radio) 15 for the longest time because there are not many things that can break. It seems like that. For example, this one has a turning wheel. It seems like it would last for a long time."

\subsection{Desirable Design Characteristics of Refurbished Products}

In addition to the insights on the specific associations of the neo-retro and simplistic design styles, our results also uncovered general design characteristics that were desired in refurbished products. Product characteristics related to the quality of the product, the durability, and the repairability could serve as strategies in how to further enhance the consumer acceptance of refurbished products.

Participants stated that generally only products that are of high quality should be refurbished. They mentioned that the quality of the product was an important criterion when choosing a refurbished product, but if the quality was guaranteed, the looks of the product determined the product choice.

Participant 12: "Modern Products can Be Reused. But the only Products that can Be Reused Are Products that Are Well-Built Because, Yes, They [the Products] Have to be Built for Longevity in order to be Reusable." 
Complex products or products with fragile parts, such as the sleek headpiece in headphone number 10 , were seen as breakable and therefore, unfavorable because they were perceived to be less durable. In contrast, participants preferred robust and solid designs in refurbished products as these were believed to be more durable and less likely to break after purchase.

Participant 19: "With number 9, 10 and 12, I have something like: If something was broken, what can you still repair? I think that they would break after a period of time. I think I would rather buy something more solid."

Participants appreciated the use of wood, metal, and leather in refurbished products. Metal and brushed aluminum were deemed desirable because of two reasons: First of all, metal products were perceived to be more repairable than plastic products, and it was easier to determine whether products are in a good state. Wood was associated with warm feelings and the product having a narrative.

Participant 21: "A chair with a leather or wooden seat can tell a story better than a Rotan (Ikea) chair because of the wear that it breaks down more beautifully than the other."

Secondly, metal products were associated with increased durability, whereas plastic was perceived to be less durable. Most refurbished products in the neo-retro design style benefitted from the positive perceptions of these materials, as neo-retro products often include wood, leather, and metal.

Refurbished products that looked like they were repairable were modular or consisted of different, non-integrated parts, were more desirable in a refurbished state because they could be repaired easily by the consumer and/or the refurbishers. Consumers assumed that repairable products are also more likely to be successfully refurbished and therefore, more durable and trustworthy than products that were not repairable.

Participant 5: "If something is to be refurbished, the question is what exactly can be refurbished. With many coffee machines, you can't even open them anymore. At least that's what I read some time ago. So there is nothing that you can repair about them anymore."

\section{General Discussion}

The circular economy is a promising path towards more sustainable production of consumer goods. One challenge within the circular economy is, however, that current circular products, such as refurbished products, are often not considered a desirable and viable alternative to new products by consumers $[8,9]$. While prior research on consumer acceptance of refurbished products has explored the functional characteristics of refurbished products $[7,21,22]$ or why refurbished products are not a desirable consumer choice to most consumers [8,9], research on how to make refurbished products more attractive via design is sparse [22]. This research contributes to the current literature on consumer acceptance of refurbished products $[9,18,19,22]$ by exploring the value of the product appearance of refurbished products for enhancing consumer acceptance. Prior research has only focused on either verbal or visual information of refurbished products [22] or on the aesthetics of new products [29-38]. Building on prior research, we conducted the first qualitative study that combines knowledge on the product aesthetics of new products and knowledge on the consumer response to refurbished products. Thereby we explored potential pathways to design product appearances that remain appealing across multiple product lifecycles in refurbished products. Specifically, we focus on the value of timeless designs for enhancing consumer acceptance of refurbished products.

To summarize, our findings provide qualitative support that the neo-retro and simplistic design styles are considered to be timeless and elicit associations in consumers that are especially favorable in a refurbished state (see Table 2). Nostalgia evoking designs of new products, including the neo-retro design style [41], were suggested to be timeless and contribute to product longevity by integrating values, such as fine craft, innovation, and the historical context into the design [33]. In our study, refurbished coffee makers, headphones and radios following a neo-retro design style additionally 
benefited from being associated with the good quality of the past, when products were made to last and to have an eternally beautiful appearance. This is especially desirable for refurbished products because they are, by definition, older than newly manufactured products.

Table 2. Summary of differences between refurbished neo-retro products, refurbished simplistic products, and refurbished prototypical products.

\begin{tabular}{|c|c|c|c|}
\hline & $\begin{array}{l}\text { Refurbished Products in a } \\
\text { Neo-retro Design }\end{array}$ & $\begin{array}{l}\text { Refurbished Products in a } \\
\text { Simplistic Design }\end{array}$ & $\begin{array}{l}\text { Refurbished Products in a } \\
\text { Prototypical Design }\end{array}$ \\
\hline Timelessness & $\begin{array}{l}\text { Refurbished neo-retro products } \\
\text { were described as being } \\
\text { timeless. }\end{array}$ & $\begin{array}{l}\text { Refurbished simplistic products } \\
\text { were described as being } \\
\text { timeless. }\end{array}$ & $\begin{array}{l}\text { Refurbished prototypical } \\
\text { products were perceived to be } \\
\text { out of fashion in the near future }\end{array}$ \\
\hline Quality & $\begin{array}{l}\text { Refurbished neo-retro products } \\
\text { were perceived to be more } \\
\text { durable because they evoked } \\
\text { associations with the good } \\
\text { quality of the past. }\end{array}$ & $\begin{array}{l}\text { Refurbished simplistic products } \\
\text { were associated with quality } \\
\text { because they reminded people of } \\
\text { brands known for their quality. }\end{array}$ & $\begin{array}{l}\text { Refurbished prototypical } \\
\text { products were not associated } \\
\text { with high quality. }\end{array}$ \\
\hline Durability & $\begin{array}{l}\text { Refurbished neo-retro products } \\
\text { were associated with durability } \\
\text { from the past. }\end{array}$ & $\begin{array}{l}\text { Refurbished simplistic products } \\
\text { were associated with durability } \\
\text { because they looked so simple } \\
\text { that nothing could break. Sleek } \\
\text { parts were not desirable in } \\
\text { refurbished products. }\end{array}$ & $\begin{array}{l}\text { Only refurbished prototypical } \\
\text { products with solid designs } \\
\text { were associated with high } \\
\text { durability. }\end{array}$ \\
\hline Narrative & $\begin{array}{l}\text { Refurbished neo-retro products } \\
\text { are more likely to have a } \\
\text { narrative, reminded people of } \\
\text { the past (e.g., the } 50 \text { s and } 60 \text { s), } \\
\text { created memories and therefore } \\
\text { had emotional value. }\end{array}$ & $\begin{array}{l}\text { Simplistic products were not } \\
\text { associated with a narrative but } \\
\text { often associated with iconic } \\
\text { Braun and Apple products from } \\
\text { the past. }\end{array}$ & $\begin{array}{l}\text { Refurbished prototypical } \\
\text { products were not associated } \\
\text { with a narrative. }\end{array}$ \\
\hline Appearance & $\begin{array}{l}\text { Refurbished neo-retro products } \\
\text { were described to have a unique, } \\
\text { prominent extravagant, } \\
\text { beautiful appearance. }\end{array}$ & $\begin{array}{l}\text { Refurbished simplistic products } \\
\text { were perceived to have an } \\
\text { inconspicuous appearance. }\end{array}$ & $\begin{array}{l}\text { The appearance of refurbished } \\
\text { prototypical products was not } \\
\text { mentioned by participants. }\end{array}$ \\
\hline
\end{tabular}

New products with simplistic designs were, in turn, suggested to be timeless because they are disconnected from cues indicating a specific period of time [24]. In our study, refurbished products following a simplistic design style were not only associated with being timeless but also benefited from associations of greater durability through simplicity and associations with high-quality brands.

Durability was a re-emerging theme in general; participants favored refurbished products with a solid over sleek product appearance and preferred refurbished products made of high-quality materials, such as wood, leather, and metal because of their durability.

\subsection{Practical Implications}

Our findings have several practical implications for companies and designers aiming to implement refurbishment and, thereby, encourage circular consumption. By purposefully applying associations that the neo-retro and simplistic design styles evoke, as well as the general design characteristics, in the design process of the appearance of refurbished products, designers can design products that are more likely to be desirable after refurbishment. This has the potential to create products that are attractive for longer and will last for multiple life cycles. It is an especially interesting strategy for many consumer electronics that are discarded prematurely [6].

Extending the lifetime of a product via refurbishment has implications for the production as well as the business model of the producer. First, products need to be designed for longevity to make refurbished products attractive. Designers should put an emphasis on the timelessness, durability, and quality of the product when designing the first version of the product. This can extend the product's life span and would consequently slow loops currently employed in business models [49]. Second, designing for longevity may increase production costs for the first version of the product. If the product is, however, perceived as timeless and the original equipment manufacturer refurbishes the product, 
initial production costs could be compensated by the financial advantages that refurbishment offers after reselling the product.

One potential drawback about implementing design styles that can evoke associations of timelessness is the fact that, in the end, all trends are cyclical and evolve over time. Even though some trends are moving faster than others, it is probably inconceivable to design consumer electronics that will remain desirable for numerous decades. It is also questionable whether the designs that are considered neo-retro today will remain to be perceived as neo-retro. Furthermore, even though prototypes of products do not change frequently, these do evolve in time. Prototypes are "cognitive reference points" that consumers use to determine whether a product belongs to a certain product category [50] (p. 533). Shared characteristics, that products of the same category have, determine the prototype. For example, in the past, a telephone's handle was considered a prototypical characteristic of a telephone. Nowadays, telephones are mobile, and most telephones do not have handles anymore. A high degree of prototypicality has shown to have a positive effect on the attractiveness of products and, therefore, should be taken into consideration when designing for timelessness [26,35,37]. Even though these time effects need to be taken into account and limit the 'eternal' desirability of timeless products, this does not mean that timelessness may not contribute to circular consumption. Lifespans of many product categories are decreasing. For example, the lifespan of coffee machines decreased from 2000 to 2005 with $9 \%$ to only 6.4 years [51]. A successful refurbishment strategy and thus, a second or even third life, may turn the overall lifespan of coffee machines to 12 or more years. In many cases, such an increase in lifespan would, from an environmental perspective, be valuable but is not likely to be strongly affected by changes in fashion cycles or prototypes.

Even though our results suggest that neo-retro and simplistic design styles trigger specific associations that can improve consumers' evaluations, we also realize that the final value of these design styles may differ depending on the consumer group and the product category. First of all, consumers differ in their aesthetic preferences [39]. For example, highly educated consumers who are above 50 years old prefer designs that refer to a historic context, such as neo-retro designs, whereas consumers that are lower educated and younger (below 36) prefer tough designs, characterized by power and strength. Consequently, the simplistic and the neo-retro design styles may be more influential for highly educated, older consumers than for younger and lower educated consumer groups.

Whether designing a product in a neo-retro or simplistic style is a good design strategy to enhance consumer acceptance of refurbished products also depends on the product category of the refurbished product. Our results suggest that product categories that are not highly technological, such as coffee machines and radios, can benefit from the positive effects of the neo-retro design style. Nevertheless, it is questionable whether product categories that are continuously advancing in terms of technology, such as smartphones, will also benefit as the association with an 'old' product may then backfire in terms of quality perceptions. In this situation, a simplistic design style could be a more desirable strategy.

\subsection{Limitations and Future Research}

A limitation of our research is that we took a qualitative approach to uncover the associations that different timeless designs would trigger with consumers, resulting in a relatively small sample size. We believe that our sample size was sufficient for the exploratory focus of our research, which was also supported by the fact that data saturation was reached after 18 interviews. Nevertheless, it would be worthwhile to investigate the effects of timeless designs in more quantitative settings using larger samples. Furthermore, in real purchase settings, consumers often compare refurbished products to new products. It would be interesting for future research to investigate the effects of the design characteristics of refurbished products in choice settings using quantitative research to further validate our findings.

Future research should also explore how the perceptions of refurbished products of various consumer groups differ in detail, using a quantitative approach. 
Additionally, our study only explored how consumers perceive the neo-retro and simplistic design style in refurbished products. It is, however, unclear whether the same effect will account for new products as well, resulting in a potentially longer first life of the product. Future research needs to explore what role refurbishment plays in the associations that consumers make with neo-retro and simplistic products; perhaps in a comparative study between refurbished products and new products.

Future research is needed to translate and further validate our findings into design guidelines for designers. For example, in our qualitative study, we were not able to distinguish between the effects of the design styles and the effects of specific, general design characteristics. In fact, some general design characteristics are more prevalent in one design style than others. For example, participants preferred products made of wood, leather, and metal because they seemed durable and to age more gracefully. Leather, wood, and metal were most prevalent in the neo-retro products in our study. Another example is that participants preferred refurbished products with a robust appearance compared to products with sleek parts because they are expected to be less breakable. Most neo-retro products had robust appearances. It is, therefore, interesting for future research to investigate in an experimental setting whether the value of the neo-retro design style for enhancing consumer acceptance of refurbished products is due to the materials and form of the products or due to the associations that the design style evokes in consumers.

Additionally, we acknowledge that even though participants in our study were generally positive about the use of neo-retro and simplistic design styles in refurbished products, this may not be true for all products following these styles. More research is needed to explore what makes some simplistic and neo-retro products attractive, whereas others are considered inauthentic or cheap.

Finally, future research could explore the value of appearance, and specifically, specific design styles and design characteristics, for enhancing consumer acceptance of different circular strategies. For products that are circulating among multiple users, such as in sharing systems, other design characteristics may be more important, such as design characteristics that emphasize hygiene [18].

\subsection{Conclusions}

Refurbishment is a promising circular strategy that can make the production of consumer goods more sustainable by saving finite resources and minimizing waste. Refurbished products are, however, not a desirable consumer choice to most consumers yet, partly because the aesthetic appearance of refurbished products is considered less attractive than the appearance of new products.

In this research, we explored whether enhancing the product appearance of refurbished products, by means of two types of timeless design styles, can increase the consumer acceptance of refurbished products. We uncovered that refurbished products in the neo-retro design style and in the simplistic design style evoke favorable perceptions in consumers and subsequently enhance the attractiveness of refurbished products. By considering these findings in the design process, we hope to inspire further research to inform designers on making circular products that remain desirable in multiple life cycles and, therefore, stimulate sustainable consumption with circular products.

Author Contributions: The research was collaboratively conducted by the research team as T.S.W. is a PhD candidate supervised by L.M. and R.M. The research contribution was distributed in the following manner: “Conceptualization, T.S.W., L.M., and R.M.; methodology, T.S.W., R.M., and L.M.; analysis, T.S.W., R.M., and L.M.; investigation, T.S.W.; writing-Original draft preparation, T.S.W.; writing-Review and editing, L.M. and R.M., revision, R.M. and T.S.W.; supervision, R.M. and L.M.; project administration, T.S.W. All authors have read and agreed to the published version of the manuscript.

Funding: This research received no external funding.

Acknowledgments: We would like to thank Agnes Tan and her assistants for helping us with the administrative work required when approaching participants.

Conflicts of Interest: The authors declare no conflict of interest. 


\section{Appendix A}

Table A1. Differences between refurbished neo-retro products and refurbished simplistic products.

\begin{tabular}{cccc}
\hline Product & $\begin{array}{c}\text { MEAN } \\
\text { Neo-Retro }\end{array}$ & $\begin{array}{c}\text { MEAN } \\
\text { Simplistic }\end{array}$ & $\begin{array}{c}\text { MEAN } \\
\text { Prototypical }\end{array}$ \\
\hline 1. Neo-retro coffee maker & 6.47 & 2.67 & 4.33 \\
2. Neo-retro coffee maker & 6.13 & 2.67 & 4.20 \\
3. Simplistic coffee maker & 2.33 & 6.40 & 3.53 \\
4. Simplistic coffee maker & 3.13 & 5.80 & 2.40 \\
5. Prototypical coffee maker & 4.0 & 3.93 & 4.60 \\
6. Prototypical coffee maker & 2.67 & 3.35 & 4.40 \\
7. Neo-retro headphone & 6.0 & 3.14 & 3.86 \\
8. Neo-retro headphone & 5.93 & 1.64 & 2.93 \\
9. Simplistic headphone & 2.86 & 5.71 & 3.14 \\
10. Simplistic headphone & 2.07 & 6.21 & 3.14 \\
11. Prototypical headphone & 3.29 & 4.79 & 5.57 \\
12. Prototypical headphone & 2.79 & 3.64 & 4.14 \\
13. Neo-retro radio & 6.15 & 4.0 & 5.38 \\
14. Neo-retro radio & 5.62 & 4.00 & 5.38 \\
15. Simplistic radio & 2.64 & 6.43 & 3.5 \\
16. Simplistic radio & 3.67 & 5.40 & 4.20 \\
17. Prototypical radio & 3.23 & 2.62 & 5.23 \\
18. Prototypical radio & 3.86 & 3.36 & 4.86 \\
\hline
\end{tabular}

Table A2. Overview of overall topics and themes that were coded. First-order and second-order codes were left out because the table serves to give an overview of the topics.

\begin{tabular}{ll}
\hline Overall Topic & Theme \\
\hline \multirow{2}{*}{ Motivations to buy refurbished products } & Economic benefits of refurbishment \\
& Environmental benefits of refurbishment \\
Desirable design characteristics of & Need for quality in refurbished products \\
refurbished products & Breakability of the design \\
& Material choice of refurbished products determines desirability, \\
Negative associations with refurbished & quality perceptions and whether product has a narrative \\
products & Contamination issues of refurbished products \\
When wear and tear is acceptable & Associations with planned obsolescence \\
& When wear and tear is not acceptable on refurbished products \\
& When wear and tear is acceptable on refurbished products \\
& Neo-retro products evoke associations with the past \\
The evaluation of the neo-retro design style & Neo-retro products evoke associations with a narrative \\
& Neo-retro products evoke nostalgic feelings \\
& Neo-retro products have a special design \\
& Neo-retro products are timeless \\
& Simplistic products are timeless \\
& Simplistic products evoke associations with high quality \\
& though brand associations \\
& Simplistic products look simple and easy to use \\
Evaluation of the simplistic design style & Simplistic products are durable through simplicity \\
& Simplistic product can look cheap \\
Antiques are old & Antiques have a story \\
& Antiques have a special design \\
& Antiques are from a different design period \\
& Antiques are valuable \\
Antiques are of high quality
\end{tabular}


Table A2. Cont.

\begin{tabular}{ll}
\hline Overall Topic & Theme \\
\hline & Differences in use \\
& Differences in repair \\
Differences between refurbished products & Differences in age \\
and antiques & Differences in value \\
& Differences in technology \\
& Differences in diversion (end of life of the product) \\
& Antiques evoke more feelings than refurbished products \\
\hline
\end{tabular}

\section{References}

1. Waste Electrical and Electronic Equipment (WEEE) by Waste Management on Eurostats Website. Available online: https://ec.europa.eu/eurostat/cache/metadata/en/env_waselee_esms.htm (accessed on 20 December 2019).

2. Waste Management and the Circular Economy in Selected OECD Countries. Organisation for Economic Co-operation and Development. Available online: https://www.oecd.org/environment/waste-managementand-the-circular-economy-in-selected-oecd-countries-9789264309395-en.htm (accessed on 23 September 2019).

3. Geissdoerfer, M.; Savaget, P.; Bocken, N.M.; Hultink, E.J. The Circular Economy-A new sustainability paradigm. J. Clean. Prod. 2017, 143, 757-768. [CrossRef]

4. Pigosso, D.C.A.; Zanette, E.T.; Filho, A.G.; Ometto, A.R.; Rozenfeld, H. Ecodesign methods focused on remanufacturing. J. Clean. Prod. 2010, 18, 21-31. [CrossRef]

5. Kaddoura, M.; Kambanou, M.L.; Tillman, A.M.; Sakao, T. Is Prolonging the Lifetime of Passive Durable Products a Low-Hanging Fruit of a Circular Economy? A Multiple Case Study. Sustainability 2019, 11, 4819. [CrossRef]

6. Cox, J.; Griffith, S.; Giorgi, S.; King, G. Consumer understanding of product lifetimes. Resour. Conserv. Recycl. 2013, 79, 21-29. [CrossRef]

7. Hatcher, G.D.; Ijomah, W.L.; Windmill, J.F.C. Design for remanufacture: A literature review and future research needs. J. Clean. Prod. 2011, 19, 2004-2014. [CrossRef]

8. Mugge, R.; Jockin, B.; Bocken, N. How to sell refurbished smartphones? An investigation of different customer groups and appropriate incentives. J. Clean. Prod. 2017, 147, 284-296. [CrossRef]

9. Mugge, R.; Safari, I.; Balkenende, R. Is there a market for refurbished toothbrushes? An exploratory study on consumers' acceptance of refurbishment for different product categories. In Proceedings of the Product Lifetimes and the Environment (PLATE 2017), Delft, The Netherlands, 9-10 November 2017; pp. $293-297$.

10. Dominish, E.; Retamal, M.; Sharpe, S.; Lane, R.; Rhamdhani, M.A.; Corder, G.; Giurco, D.; Florin, N. "Slowing" and "Narrowing" the Flow of Metals for Consumer Goods: Evaluating Opportunities and Barriers. Sustainability 2018, 10, 1096. [CrossRef]

11. Harms, R.; Linton, J.D. Willingness to Pay for Eco-Certified Refurbished Products: The Effects of Environmental Attitudes and Knowledge: WTP for Eco-certified Refurbished Products. J. Ind. Ecol. 2016, 20, 893-904. [CrossRef]

12. Michaud, C.; Llerena, D. Green consumer behaviour: An experimental analysis of willingness to pay for remanufactured products. Bus. Strateg. Environ. 2010, 20, 408-420. [CrossRef]

13. Guide, V.D.R., Jr.; Li, J. The potential for cannibalization of new products sales by remanufactured products. Decis. Sci. 2010, 41, 547-572. [CrossRef]

14. Hamzaoui Essoussi, L.; Linton, J.D. New or recycled products: How much are consumers willing to pay? J. Consum. Mark. 2010, 27, 458-468. [CrossRef]

15. Wang, Y.; Wiegerinck, V.; Krikke, H.; Zhang, H. Understanding the purchase intention towards remanufactured product in closed-loop supply chains: An empirical study in China. Int. J. Phys. Distrib. Logist. Manag. 2013, 43, 866-888. [CrossRef]

16. Pang, G.; Casalin, F.; Papagiannidis, S.; Muyldermans, L.; Kei Tse, Y. Price determinants for remanufactured electronic products: A case study on eBay UK. Int. J. Prod. Res. 2015, 53, 572-589. [CrossRef] 
17. Atasu, A.; Sarvary, M.; Van Wassenhove, L.N. Remanufacturing as a Marketing Strategy. Manag. Sci. 2008, 54, 1731-1746. [CrossRef]

18. Baxter, W.; Aurisicchio, M.; Mugge, R.; Childs, P. Decontaminating experiences with circular offerings. In Proceedings of the Product Lifetimes and the Environment (PLATE 2017), Delft, The Netherlands, 9-10 November 2017; pp. 32-36.

19. van Weelden, E.; Mugge, R.; Bakker, C. Paving the way towards circular consumption: Exploring consumer acceptance of refurbished mobile phones in the Dutch market. J. Clean. Prod. 2016, 113, 743-754. [CrossRef]

20. Ijomah, W.L.; McMahon, C.A.; Hammond, G.P.; Newman, S.T. Development of design for remanufacturing guidelines to support sustainable manufacturing. Robot. Comput. Integr. Manuf. 2006, 23, 712-719. [CrossRef]

21. Östlin, J.; Sundin, E.; Björkman, M. Importance of closed-loop supply chain relationships for product remanufacturing. Int. J. Prod. Econ. 2008, 115, 336-348. [CrossRef]

22. Mugge, R.; de Jong, W.; Person, O.; Hultink, E.J. 'If It Ain't Broke, Don't Explain It': The Influence of Visual and Verbal Information about Prior Use on Consumers' Evaluations of Refurbished Electronics. Des. J. 2018, 21, 499-520. [CrossRef]

23. Mugge, R.; Dahl, D.W.; Schoormans, J.P. “What You See, Is What You Get?” Guidelines for Influencing Consumers' Perceptions of Consumer Durables through Product Appearance. J. Prod. Innov. Manag. 2018, 35, 309-329. [CrossRef]

24. Lobos, A. Timelessness in sustainable product design. In Proceedings of the 9th International Conference on Design \& Emotion, Bogota, Colombia, 6-10 October 2014; pp. 169-176.

25. Parsons, G. The Philosophy of Design; Polity Press: Cambridge, UK, 2016; ISBN 978-0-7456-6388-3.

26. Bloch, P.H. Seeking the ideal form: Product design and consumer response. J. Mark. 1995, 59, 16-29. [CrossRef]

27. Crilly, N.; Moultrie, J.; Clarkson, P.J. Seeing things: Consumer response to the visual domain in product design. Des. Stud. 2004, 25, 547-577. [CrossRef]

28. Creusen, M.E.; Schoormans, J.P. The different roles of product appearance in consumer choice. J. Prod. Innov. Manag. 2005, 22, 63-81. [CrossRef]

29. Mugge, R. The Effect of a Business-like Personality on the Perceived Performance Quality of Products. Int. J. Des. 2011, 5, 67-76.

30. Mugge, R.; Schoormans, J.P. Product design and apparent usability. The influence of novelty in product appearance. Appl. Ergon. 2012, 43, 1081-1088. [CrossRef]

31. Page, C.; Herr, P.M. An investigation of the processes by which product design and brand strength interact to determine initial affect and quality judgments. J. Consum. Psychol. 2012, 12, 133-147. [CrossRef]

32. Loos, A. Ornament and Crime (1908) in Programs and Manifestoes on 20th-century Architecture; MIT Press: Cambridge, MA, USA, 1971; Chaper 4; pp. 12-24. ISBN 0-262-530-30-9.

33. Flood Heaton, R.; McDonagh, D. Can timelessness through prototypicality support sustainability? A strategy for product designers. Des. J. 2017, 20, 110-121. [CrossRef]

34. Dion, K.; Berscheid, E.; Walster, E. What is beautiful is good. J. Pers. Soc. Psy. 1972, 24, 285-290. [CrossRef]

35. Hekkert, P.; Snelders, D.; Van Wieringen, P.C. 'Most advanced, yet acceptable': Typicality and novelty as joint predictors of aesthetic preference in industrial design. Br. J. Psychol. 2003, 94, 111-124. [CrossRef]

36. Veryzer, J.R.W.; Hutchinson, J.W. The influence of unity and prototypicality on aesthetic responses to new product designs. J. Consum. Res. 1998, 24, 374-394. [CrossRef]

37. Blijlevens, J.; Carbon, C.C.; Mugge, R.; Schoormans, J.P. Aesthetic appraisal of product designs: Independent effects of typicality and arousal. Br. J. Psychol. 2012, 103, 44-57. [CrossRef]

38. Creusen, M.E.; Schoormans, J.P.; Veryzer, R.W. The relationship between design typicality, novelty and aesthetic judgments. In Proceedings of the European Advances in Consumer Research, Goteborg, Sweden, 15-18 June 2005; pp. 502-503.

39. Snelders, D.; Mugge, R.; Huinink, M. Using social distinctions in taste for analysing design styles across product categories. Int. J. Des. 2014, 8, 23-34.

40. Haines-Gadd, M.; Chapman, J.; Lloyd, P.; Mason, J.; Aliakseyeu, D. Emotional durability design nine-A tool for product longevity. Sustainability 2018, 10, 1948. [CrossRef]

41. Fort-Rioche, L.; Ackermann, C.L. Consumer innovativeness perceived innovation and attitude towards "neo-retro"-product design. Eur. J. Innov. Manag. 2013, 16, 495-516. [CrossRef] 
42. Mugge, R.; Schoormans, J.P.L.; Schifferstein, H.N.J. Design strategies to postpone consumers' product replacement: The value of a strong person-product relationship. Des. J. 2005, 8, 38-48. [CrossRef]

43. Rams, D. Less and More. The Design Ethos of Dieter Rams; Die Gestalten Verlag: Berlin, Germany, 2015; ISBN 13-978-389-955-584-4.

44. Dieter Rams: The Legendary Designer who Influenced Apple. Available online: https:/edition.cnn.com/ style/article/dieter-rams-film-exhibition-style-intl/index.html (accessed on 20 November 2019).

45. Hagaman, A.; Wutich, A. How many interviews are enough to identify Metathemes in multisited and cross-cultural research? Another perspective on Guest, Bunce, and Johnson's (2006) landmark study. Field Meth. 2017, 29, 23-41. [CrossRef]

46. Guest, G.; Bunce, A.; Johnson, L. How many interviews are enough? An experiment with data saturation and variability. Field Meth. 2006, 18, 59-82. [CrossRef]

47. Abbey, J.D.; Abbey, M.G.; Guide, V.D.R.; Atalay, S. Remanufactured products in closed-loop supply chains for consumer goods. Prod. Oper. Manag. 2015, 24, 488-503. [CrossRef]

48. Sharma, V.; Garg, S.K.; Sharma, P.B. Identification of major drivers and roadblocks for remanufacturing in India. J. Clean. Prod. 2016, 112, 1882-1892. [CrossRef]

49. Nussholz, J.L. A circular business model mapping tool for creating value from prolonged product lifetime and closed material loops. J. Clean. Prod. 2018, 197, 185-194. [CrossRef]

50. Rosch, E. Cognitive reference points. Cogn. Psych. 1975, 7, 532-547. [CrossRef]

51. Bakker, C.; Wang, F.; Huisman, J.; Den Hollander, M. Products that go round: Exploring product life extension through design. J. Clean. Prod. 2014, 69, 10-16. [CrossRef]

(C) 2020 by the authors. Licensee MDPI, Basel, Switzerland. This article is an open access article distributed under the terms and conditions of the Creative Commons Attribution (CC BY) license (http://creativecommons.org/licenses/by/4.0/). 